\title{
A Kantian Conception of Free Speech*
}

\author{
Helga Varden
}

\begin{abstract}
In this paper I provide an interpretation of Kant's conception of free speech. Free speech is understood as the kind of speech that is constitutive of interaction respectful of everybody's right to freedom, and it requires what we with John Rawls may call 'public reason.' Public reason so understood refers to how the public authority must reason in order to properly specify the political relation between citizens. My main aim is to give us some reasons for taking a renewed interest in Kant's conception of free speech, including his account of public reason. Kant's position provides resources for dealing with many of the legal and political problems we currently struggle to analyze under this heading, such as the proper distinction between the sphere of justice and the sphere of ethics, hate speech, freedom of speech, defamation, and the public guarantee of reliable media and universal education.
\end{abstract}

Keywords Freedom of speech $•$ Kant on free speech $\bullet$ Public reason $\bullet$ Government regulation of speech

\section{Introduction}

Kant is a staunch defender of free speech. In fact, some see his defense of free speech as his sole objection to Hobbes's absolutism, even if these same interpreters find it puzzling why Kant chooses free speech as the sole condition on political

*I am grateful to Deirdre Golash, Arthur Ripstein, David Sussman, Shelley Weinberg, and Howard Williams for useful input as I developed the ideas in this paper. I am also grateful to the participants in the workshop in ethics at the Department of Philosophy at the University of Illinois at Urbana-Champaign, and the audiences at AMINTAPHIL Conference "Free Speech in a Diverse World", Villanova University, Sept. 25-28, 2008 and the APA Pacific Division, Vancouver (Canada), April, 2009.

H. $\operatorname{Varden}(\varangle)$

University of Illinois at Urbana-Champaign

e-mail: hvarden@illinois.edu 
legitimacy rather than, say, a right to life. ${ }^{1}$ Given Kant's strong defense of free speech, it is also natural to think that he rejects any rightful limits on what private individuals can say to one another in public. Any such limitation, it seems, would be a limitation on free speech. At the same time, if Kant's view really is that people can communicate whatever they want - no matter how hateful, harassing or untruthful - then it doesn't have much to contribute to contemporary legal debates surrounding free speech. I will argue the contrary: a closer analysis of the texts in light of Kant's theoretical commitments reveals a powerful Kantian liberal critique of free speech.

The argument for this new Kantian critique of the scope of constitutional protection of free speech proceeds as follows. In the first part of the paper, I focus on Kant's discussion of private right - the rights private individuals hold against one another as it pertains to speech. I start by exploring Kant's general distinction between right and virtue. The distinction between right and virtue is crucial to understanding why Kant claims that most speech does not involve private wrongdoing from the point of view of right, regardless of what virtue might have to say. Consequently, most speech does not give rise to legal claims between private persons in liberal courts of law. I then outline those aspects of private interaction involving speech that lie within liberal regulation. Here I pay special attention to the Kantian treatment of threats, honor (including defamation), contractual lies, legal responsibility for the bad consequences of lies, and noisy and startling uses of words. I argue that although there is private wrongdoing in each case, on Kant's account, private individuals do not have the right to punish the wrongdoers. Because private individuals cannot realize right any punishment of private wrongdoing must be exacted by the state.

In the second part of the paper, I argue with Kant that the state sets itself up as a public authority, understood as a liberal legal and political system, by accomplishing two main tasks. First, the state secures conditions in which its citizens can interact rightfully as private individuals by securing their rights through the establishment of corresponding private and public law. Private law regulates private disagreements while public law copes with violent private aggression (private crime). Since most speech cannot give rise to private wrongdoing, the constitution

\footnotetext{
'See, for example, Paul Guyer, Kant (New York: Routledge, 2006); Sarah Williams Holtman, "Revolution, Contradiction, and Kantian Citizenship," in Kant's Metaphysics of Morals, ed. M. Timmons (New York: Oxford University Press, 2002), 209; Otfried Höffe, Immanuel Kant, trans. Marshall Farrier (Albany: SUNY Press, 1994), 186f; Wolfgang Kersting, "Kant's Concept of the State," in Essays on Kant's Political Philosophy, ed. H.L Williams (Chicago: University of Chicago Press, 1992), 143, though contrast with his "Politics, freedom, and order: Kant's Political Philosophy," in The Cambridge Companion to Kant, ed. Paul Guyer (New York: Cambridge University Press: 1992), 342; Allen D. Rosen, Kant's Theory of Justice (New York: Cornell University Press: 1993); Howard L. Williams, Kant's Political Philosophy (New York: St. Martin's Press: 1983), 198. Though this absolutist reading of Kant is particularly encouraged by "On the Common Saying: That may be Correct In Theory, but It Is of No Use in Practice", especially pp. 8: 303ff, I argue against it in "Kant's Non-Absolutist Conception of Political Legitimacy" (Kant-Studien, forthcoming). All references refer to the Prussian Academy pagination of Kant's work. I have used Mary Gregor's translations of The Metaphysics of Morals, (New York: Cambridge University Press, 1996), and of his other texts in Practical Philosophy, (New York: Cambridge University Press, 2006).
} 
both secures the citizens' rights to be so protected by private and public law and protects their right to free speech. Second, the state aims to ensure that it functions as a representative, tripartite system of liberal law and that it reconciles its monopoly on coercion with the rights of each of its citizens by securing domestic, systemic justice. Public law is the state's main tool for setting itself up with such an institutional structure. On Kant's view, I suggest, the way in which the state must establish itself as a public system of law yields a further, independent reason why liberal legal systems give such strong constitutional protection of free speech. Moreover, I argue that because of the aim to establish itself as a public system of law, the liberal state requires its public officials to distinguish between their official uses of speech and their engagement in public reason as private citizens as well as it regulates seditious speech. Finally, I argue that on the Kantian view, these systemic considerations inform the liberal state's approach to contemporary issues such as hate speech, speech amounting to harassment and blackmail.

\section{Virtuous Versus Rightful Private Speech}

In order to understand Kant's conception of free speech we need a good grasp of his conception of rightful relations in general. With this conception in hand, we can see how Kant conceives of rightful private speech. Then we can see how rightful private speech is distinguished from rightful public speech, namely that which is protected or outlawed by various public law measures, including free speech legislation.

Right, for Kant, is solely concerned with people's actions in space and time, or what he calls our "external use of choice" (6: 213f, 224ff). When we deem each other and ourselves capable of deeds, meaning that we see each other and ourselves as the authors of our actions, we "impute" these actions to each other and to ourselves. Such imputation, Kant argues, shows that we judge ourselves and each other as capable of freedom under laws with regard to external use of choice - or 'external freedom' (6: 227). Moreover, when we interact, we need to enable reciprocal external freedom, meaning that we must find a way of interacting that is consistent with everybody's external freedom. And this is where justice, or what Kant calls 'right' comes in. Right is the relation between interacting persons' external freedom such that reciprocal external freedom is realized (6: 230). This is what Kant means when he says that rightful interactions are interactions reconcilable with each person's innate right to freedom, namely the right to "independence from being constrained by another's choices... insofar as it can coexist with the freedom of every other in accordance with a universal law" (6: 237). For Kant, right requires that universal laws of freedom, rather than anyone's arbitrary choices, reciprocally regulate interacting individuals' external freedom.

The first upshot of this conception of right is that anything that concerns morality as such is beyond its proper grasp. Right concerns only external freedom, which is limited to what can be hindered in space and time (coerced), whereas morality also requires internal freedom. That is to say, morality encompasses both right and virtue, and virtue requires what Kant calls freedom with regard to "internal use of 
choice". Internal freedom requires a person both to act on universalizable maxims and to do so from the motivation of duty (6: 220f) - and neither can be coercively enforced. This is why Kant argues that only freedom with regard to interacting persons' external use of choice (right) can be coercively enforced; freedom with regard to both internal (virtue) and external use of choice - morality - cannot be coercively enforced (ibid.). Because morality requires freedom with regard to both internal and external use of choice, it cannot be enforced.

This distinction between internal and external use of choice and freedom explains why Kant maintains that most ways in which a person uses words in his interactions with others cannot be seen as involving wrongdoing from the point of view of right: "such things as merely communicating his thoughts to them, telling or promising them something, whether what he says is true and sincere or untrue and insincere" do not constitute wrongdoing because "it is entirely up to them [the listeners] whether they want to believe him or not" (6: 238). The utterance of words in space and time does not have the power to hinder anyone else's external freedom, including depriving him of his means. Since words as such cannot exert physical power over people, it is impossible to use them as a means of coercion against another. For example, if you block my way, you coerce me by hindering my movements: you hinder my external freedom. If, however, you simply tell me not to move, you have done nothing coercive, nothing to hinder my external freedom, as I can simply walk passed you. So, even though by means of your words, you attempt to influence my internal use of choice by providing me with possible reasons for acting, you accomplish nothing coercive. That is, you may wish that I take on your proposal for action, but you do nothing to force me to do so. Whether or not I choose to act on your suggestion is still entirely up to me. Therefore, you cannot choose for me. My choice to act on your words is beyond the reach of your words, as is any other means I might have. Indeed, even if what you suggest is the virtuous thing to do, your words are powerless with regard to making me act virtuously. Virtuous action requires not only that I act on the right maxims, but that I also do so because it is the right thing to do, or from duty. Because the choice of maxims (internal use of choice) and duty (internal freedom) are beyond the grasp of coercion, Kant holds that most uses of words, including immoral ones such as lying, cannot be seen as involving wrongdoing from the point of view of right.

Three further clarifications are in order before we can see how this conception of virtue and right delineates the boundaries of free speech. First, even though lying is not a wrongdoing from the point of right, it is important to emphasize that if one lies, one is indeed responsible for the bad consequences of the lie. The reason is that by lying one voluntarily sets the framework within which another person acts. If the other person accepts an invitation to trust a false statement, then the bearer of the lie is responsible for the bad consequences of the lie. For example, say I ask you for directions to the library and you, due to your extraordinarily bad sense of humor, lie thereby sending me in the wrong direction. It happens that your lie directs me through the most dangerous part of town, where I become the victim of wrongdoing. Because your lie sets the framework within which I make my choices, namely the set of facts by which I make my choice, you become partly responsible 
for what happens to me. Your words have set the framework within which I exercise my external freedom and consequently, even if unbeknownst to you, you send me into a dangerous neighborhood, you are still partly responsible for what happens to me there. Since the wrongdoing befell me as a result of your lie, you are responsible for the bad consequences resulting from it.

Second, it is important to distinguish threats of coercion from merely immoral speech. When you threaten me, you tell me that you do not intend to interact rightfully with $\mathrm{me}$ in the future. Simply saying so does not deprive me of anything that is mine, of course, but if you are serious and have the ability to make a strike against me, that is, if you really are threatening me, then you intend to back up your words with physical force. When you really threaten me, neither are you uttering 'empty words' nor are you taking yourself to be doing so. For example, assume that instead of yielding to your threat, I begin to walk away. You then move forward to block my retreat. This signals your intention to follow through with the threat. In fact, you might engage in other acts to signal that the threat is not empty. Perhaps you crush my hat under your foot or take a baseball bat to my car. In cases like these the words contained in the threat no longer function merely as speech but take on the role of communicating an intended future wrongdoing against me. Hence, threats are not considered mere speech on this view.

Third, speech must be distinguished from uses of words that debilitate others in virtue of their causal effect on their bodies. After all, words are communicated by means of sound waves, which exist in space and time and hence can have coercive power in relation to our bodies. For example, I believe that this account affirms the view that if your words debilitate another's physical functioning, whether intentionally or unintentionally, there is private wrongdoing. If you standing on the edge of a cliff, and I sneak up behind you and say 'Boo!', I am responsible for the consequences. In this case, it is the effect of the noise on your body, say the surprise or that you are startled, rather than the word ('boo') that hinders your external freedom, namely by hindering your choice to stay on the edge of the cliff. In the same vein, playing Herbjørg Kråkevik's latest album extremely loudly out the windows of my house night and day - say, to enlighten my ignorant neighbors as to the benefits of listening to contemporary Norwegian folk music - has the debilitating effect that those close by cannot concentrate on work, relax or sleep. Ultimately, the extremely loud music will result in their inability to function physically. Therefore, also in this case my speech clearly deprives others of what is theirs, namely the functioning of their bodies due to the stress created by being subject to constant high levels of noise. Nevertheless, it is not the words or their content that constitutes my wrongdoing, but the noise. The point is that when such acts significantly affect each other's physical ability to set and pursue ends with our respective means, they are coercive; such actions hinder others' external freedom. ${ }^{2}$

\footnotetext{
${ }^{2}$ The analysis therefore changes if the music is not extremely loud, but merely annoying or causing inconvenience. In these cases, the sound waves do not have the debilitating effect I' $m$ describing above. The judgment of particular cases - whether they are merely annoying, debilitating, intentional or non-intentional - befalls, as we will see shortly, to the public authority.
} 
And note that this is fully consistent with Kant's general claim that speech as such is not a private wrong since the wrongdoing involved in the three cases above arises from the fact that there is more than speech going on.

It is because people typically cannot deprive them of what is theirs by means of their speech alone that most immoral uses of words, including lies, do not involve private wrongdoing. Instead of tracking immorality in general and lies in particular, private wrongdoing merely tracks the few instances in which speech alone has coercive power. It should therefore not come as a surprise that these instances involve lying and that Kant argues that there are two cases in which the general rule does not protect the liar: first, lying as part of contractual negotiations, and second, defamation. In both cases the lies have coercive power and so constitute private wrongdoing.

The reason contractual lies have coercive power is that if I lie when I make a contract with you and you believe me, then my intention is to deprive you non-consensually of something that is yours. For example, assuming that were I honest about what you will receive for your hard-earned money, I strongly suspect you would not contract with me, say, to buy swampland in Florida. Therefore, I lie, since otherwise you would not consent to the exchange. Thus, by lying I nonconsensually deprive you of something that is yours and lying as a part of contractual negotiations is a private wrong $(6: 238,238 \mathrm{n})$.

What about defamation, how does it involve coercion? Attempts at defamation also constitute attempts non-consensually to deprive others of what is theirs, namely their good reputations as determined by their actions. Corresponding to a person's innate right to freedom, Kant argues, is that person's duty to "Be an honourable human being... Rightful honour... consists in asserting one's worth as a human being in relation to others" (6:236). To defend one's rightful honor is to defend one's right to be recognized by others solely by the deeds one has performed. Indeed, one's reputation, Kant explains, "is an innate external belonging" (6: 295); it can originally belong only to the person whose deeds are in question. If others spread falsehoods about the life she has lived, then she has the right and duty to challenge their lies publicly, for her reputation belongs only to her and to no one else. A person's reputation is not a means subject to other people's choice; it is not a means others have a right to manipulate in order to pursue their own ends. To permit this, Kant argues, would be to permit others to use your person as their own means, or to "make yourself a mere means for others" rather than also being "at the same time an end for them" (6:236).

Let me say briefly how this account of rightful honor analyzes cases like Holocaust-denial. Part of what makes denying the Holocaust different from other types of defamation is that it involves people who are no longer alive. On the Kantian approach I am advancing, one's reputation is seen as intimately connected with how one has interacted normatively with others (6: 291). To interact normatively is to be capable of normativity or capable of interacting qua 'noumena', as Kant says, and not merely 'qua phenomena' or as embodied beings governed by laws of nature. It is qua noumena that we are capable of deeds or of having actions imputed to us. And it is qua noumena that we can still be defamed long after 
we are dead. ${ }^{3}$ Because right tracks normative relations, that one is no longer alive is beside the point. What is more, anyone - "relatives or strangers" - can challenge the lies told by another on behalf of the dead. Indeed, the one challenging the defamation does so in virtue of her own duty to ensure the conditions under which we can have rightful honor (6: 295). The reason is that those who spread such lies do not only express an unwillingness to respect those they defame in particular, but also they display a general unwillingness to interact in a way compatible with the rightful honor of everyone. The absence of defamation is necessary for public opinion to be reconcilable with each person's right to freedom and the corresponding duty to be an honorable being. By defaming the dead, a person aims to falsify the public opinion, upon which everyone is dependent for rightful honor. Consequently, every member of the public has a right to challenge such lies on behalf of the dead. ${ }^{4}$

\section{Public Regulation of Speech}

The above account captures the main elements in Kant's conception of private right with regard to speech. Although we might expect that private law would track private right in liberal legal systems, we find that it doesn't. For example, if violations of rights are judged to be coercively aggressive, then they are considered crimes and hence are regulated by public law - not private law. To add to the puzzle, laws protecting citizens' rights to be protected by private rights against one another also concerns public law, namely constitutional law - not private law. To make matters even more confusing, notice that the previous analysis of rightful private speech contains no explicit mention of free speech legislation; indeed to find these laws we must look to public law. So how can we make sense of this from the Kantian

\footnotetext{
${ }^{3}$ One's good reputation should not to be understood as "a thing", Kant argues, but as "an innate external belonging, though an ideal one only, which clings to the subject as a person, a being of such a nature that I can and must abstract from whether he ceases to be entirely at his death or whether he survives as a person; for in the context of his rights in relation to others, I actually regard every person simply in terms of his humanity, hence as homo noumenon" 6: 295.

${ }^{4}$ In the Doctrine of Right Kant says that defamation is not punishable by "the criminal court", but only by "public opinion, which in accordance with the right of retribution, inflicts on him the same loss of the honor he diminishes in another", Ibid., 6: 296n. One might be tempted to conclude that Kant rejects the idea that defamation is a legal issue at all. But this would be mistaken, for in 6:295, Kant explicitly confirms that defamation after death can "take effect only in a public rightful condition, but... [it is] not based only on its constitution and the chosen statutes in it... [it is] also conceivable a priori in the state of nature and must be conceived as prior to such status, in order that laws in the civil constitution may afterwards be adapted to them." Reading defamation to be a legal issue also gains support from this passage in the Doctrine of Virtue: "false defamation... [is] to be taken before a court", Ibid., 6: 466. Consequently, when Kant argues in the Doctrine of Right that defamation cases should not be taken before a criminal court, he should be seen as identifying the proper venue for defamation cases, namely civil (rather than criminal) court. And when Kant says that the punishment should be loss of honor, he means that the proper punishment meted out by the civil court is loss of honor.
} 
perspective? After all, if the above account of private wrongdoing with regard to speech is all the Kantian has to say about the regulation of speech, then it seems that she has little to contribute to many of the puzzles the free speech discussion gives rise to, such as public laws prohibiting seditious speech, hate speech, speech amounting to harassment, blackmail, and the way in which the speech of public officials is restricted by public law. I will argue that despite initial appearances, part of the strength of Kant's approach is its ability to critique the typical structure of right and the additional public law restrictions of speech. The core Kantian insight that gives its this ability to critique, I suggest, is its proposal that free speech legislation is not primarily about how private persons interact, but about citizens' claims on their public institutions, including their right to criticize these institutions. To see how this insight is justified and how it informs the Kantian critique of free speech, I start by emphasizing two features distinguishing Kant's approach to legal obligations from much contemporary liberal thought: first, Kant maintains that right is impossible in the state of nature and, second, that public right is different in nature from private right.

The first important distinction between Kant and much contemporary liberal thought issues from Kant's argument that it is not in principle possible for individuals to realize right in the state of nature. Kant explicitly rejects the common assumption in liberal theories of his time as well as today that virtuous private individuals can interact in ways reconcilable both with one another's right to freedom and their corresponding innate and acquired private rights. All the details of this argument are beyond the scope of this paper. It suffices to say that ideal problems of assurance and indeterminacy regarding the specification, application and enforcement of the principles of private right to actual interactions lead Kant to conclude that rightful interaction is in principle impossible in the state of nature. ${ }^{5}$ Kant argues that only a public authority can solve these problems in a way reconcilable with everyone's right to freedom. This is why we find Kant starting his discussion of public right with this claim:

\begin{abstract}
however well disposed and right-loving men might be, it still lies a priori in the rational idea of such a condition (one that is not rightful) that before a public lawful condition is established individual human beings... can never be secure against violence from one another, since each has her own right to do what seems right and good to her and not be dependent upon another's opinion about this $(6: 312){ }^{6}$
\end{abstract}

There are no rightful obligations in the state of nature, since in this condition might ('violence', or arbitrary judgments and 'opinion' about 'what seems right and good') rather than right (freedom under law) ultimately governs interactions. According to

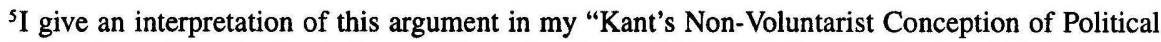
Obligations: Why Justice is Impossible in the State of Nature," Kantian Review, Vol. 13, No. 2 (2008): 1-45.

${ }^{6} \mathrm{To}$ stay faithful to Kant's own text, I have replaced Mary Gregor's translation of "rechtliebend" ('law-abiding') with 'right-loving'. Moreover, Gregor uses 'it' instead of a 'him' or 'her' here, and since this is confusing, I have replaced it with 'her.' 
Kant, therefore, only the establishment of a public authority can enable interaction in ways reconcilable with each person's innate right to freedom. Moreover, only a public authority can ensure interaction consistent with what Kant argues are our innate rights (to bodily integrity and honor) and our acquired rights (to private property, contract and status relations). The reason is that only the public authority can solve the problems of assurance and indeterminacy without violating anyone's right to freedom. The public authority can solve these problems because it represents the will of all and yet the will of no one in particular. Because the public authority is representative in this way - by being "united a priori" or by being an "omnilateral" will (6: 263) - it can regulate on behalf of everyone rather than on behalf of anyone in particular. For these reasons, civil society is seen as the only means through which our interactions can become subject to universal laws that restrict everyone's freedom reciprocally rather than as subject to anyone's arbitrary choices.

The second related distinction between Kant and much contemporary liberal thought concerns Kant's explicit challenge of the (typically implicit) liberal assumption that the reasoning and actions of the public authority should be thought of as analogous to the reasoning and actions of virtuous private individuals. This line of reasoning is typically assumed by both weak and strong voluntarist theories. On such views, 'public reason' is seen as referring to what virtuous individuals would or could hypothetically consent to. Instead, Kant proposes that the reasoning and actions of the public authority should be, exactly, public, meaning that any decisions or actions should be such that all citizens (whether virtuous or not) could hypothetically consent to them. To represent the citizens properly, then, the public authority must reason within a framework set by its citizens' rights. This is why Kant emphasizes that the citizens' hypothetical consent is understood as what citizens would consent to simply as citizens (6: 314$))^{7}$ And as citizens their aim is to enable a condition in which rightful interaction, or interaction consistent with everyone's right to freedom, is possible - exactly what is not possible in the state of nature. The perspective of the public authority is therefore not an idealized perspective of personal virtue or of private right, but rather a common public perspective constitutive of a rightful condition. Establishing such a public perspective to regulate citizens' interactions is necessary for rightful interaction on this view.

When the state comes into being, Kant therefore argues, " $[\mathrm{t}]$ he general will of the people has united itself into a society which is to maintain itself perpetually" (6: 326). The state must ensure that it sets up with an institutional structure that enables it to remain a public authority in perpetuity. Moreover, any liberal state, Kant argues, is a representative republic, in which the people is the sovereign by governing itself through public institutions. In the just state, therefore, "law itself rules and depends on no particular person... Any true republic is and can only be

${ }^{7}$ Ibid., 6: 314. Rawls seems to share this feature with Kant. It is especially prominent in his later writings (Political Liberalism onwards) since there he increasingly emphasizes both the public aspect of his theory as well as that the theory is based on the citizens' two moral capacities. 
a system representing the people, in order to protect its rights in its name, by all the citizens united and acting through their delegates (deputies)" (6: 341). The public authority comprises a liberal system of law aimed at enabling rightful interaction and whose officers are to be seen as the citizens' delegates or deputies. By the latter point Kant does not identify democracy as a minimal condition on a state's legitimacy. ${ }^{8}$ Rather what is taken to be crucial is that the public authority is exercised within the parameters set by a firm commitment to act on behalf of the citizens. The aim, therefore, is not to construct an ideally virtuous, artificial person, but an artificial person who represents only its citizens, and yet no one of them in particular. To do this, the state must be established as a representative, liberal system of law. Therefore, the state does or must do something private individuals cannot in principle do, namely act solely as a representative of the people by establishing itself as the liberal rule of law.

How, then, does the public authority go about establishing itself as a representative authority in the right way? One condition is that the public authority cannot have any private interests: it cannot own land or private property (6: 323f). If it did, it would simply be a powerful private person, and so would reintroduce the problems of the state of nature in its most ghastly forms. Another condition is that the public authority as a sovereign power must be a tripartite authority whose powers are delineated by the social contract (the constitution) which legislates (posits laws); which judges (applies the posited laws), and which determines the execution of the law (upholds a monopoly on coercion) (6: 316-318). In addition, the public authority's monopoly on coercion must be reconcilable with each citizen's innate right to freedom as well as her corresponding innate rights (to honor and bodily integrity) and acquired rights (to private property, contract and status relations). Hence, because the public authority's primary aim is to overcome the problems of assurance and indeterminacy in the state of nature, and thus establish reciprocal freedom under law, Kant maintains that its authority must be thoroughly delineated by posited law that is also consistent with the "a priori necessary... laws... [that] follow of themselves from concepts of external right as such" (6: 313 , cf. $6: 315$ ). And as we have seen, this entails that posited law must be consistent with the a priori principles of private right. Otherwise, interaction cannot be reciprocal freedom subject to universal law. Making the principles of private right (bodily integrity, honor, property, contract and status) determinate by positing laws, which are applied by the courts and enforced by the executive power is therefore constitutive of establishing a public authority at all; its legitimacy requires that it enables reciprocal freedom under law in this way. In sum, then, constitutive of establishing a state is a legal, foundational or constitutional document that secures each citizen her right to freedom, which includes the right to bodily integrity, rightful honor, private property, contract right and status relations. Herein lies the reason why most communications of words as such as well as

${ }^{8}$ Kant considers there to be three forms of state, namely autocracy (rule by one), aristocracy (rule by nobility) and democracy (rule by the many), (6:340). 
virtue are beyond the proper boundaries of law: they fall outside the sphere of proper liberal legislation of private interaction constitutive of a legitimate public authority. Consequently private citizens do not have legal rights against one another regarding their speech, except insofar as their communications of thought are defamatory or are part of contractual relations, namely cases in which through speech we can deprive one another of rightful possessions. It is in part for this reason that the resulting Kantian position will defend citizens' constitutional right to free speech, understood as their right to discuss even the most controversial topics amongst themselves - through films, articles, the media, internet medium, and so on. And it is in part because citizens cannot have a right to take each other to court on these issues that legal protection of free speech is protected by public law rather than private law - it is a right the citizens hold against the state rather than against one another. Establishing a just state involves giving its citizens a constitutional right to be so protected. ${ }^{9}$

It would be tempting, but wrong, to conclude from the above that a full liberal critique of free of speech rights found in liberal states can be established by means of an account derived, ultimately, from private persons' rights against one another. For then Kant would be seen as arguing that constitutional protection of free speech is merely about ensuring that people are not punished when speech does not involve private wrongdoing. But Kant's defense of free speech is much stronger than this. On his view, crucially, the right to free speech also protects the possibility of criticism of the public authority, since the right to speak out against the state is necessary for the public authority to be representative in nature. Therefore, this right to free speech is constitutive of the legitimacy of the political authority, namely constitutive of the political relation itself - a relation that does not exist in the state of nature. The right to political speech therefore does not rely on the justification provided by the private right argument that words cannot coerce. This aspect of the right to free speech is rather seen as following from how the public authority must protect and facilitate its citizens' direct, critical engagement with public, normative standards and practices as they pertain to right. There are no a priori solutions or knowledge with regard to the actual formulation of the wisest laws and policies to enable rightful interaction. It is only through public discussion protected by free speech that the public authority can reach enlightenment about how and whether its

'In "A Kantian Conception of Rightful Sexual Relations: Sex, (Gay) Marriage and Prostitution," Social Philosophy Today, Vol. 22 (2007): 199-218, I argue that it is because citizens have a right to access protection by private right that gays and lesbians have a right to marriage. This is why same-sex marriage is a constitutional right. In "A Kantian, Feminist Conception of Abortion and Homosexuality," in Analytical Feminist Contributions to Traditional Philosophy, eds. Anita M. Superson and Sharon Crasnow, I argue similarly that sodomy and abortion laws are constitutional issues; they involve rights to bodily integrity and hence are covered in US law under the term 'a right to privacy'. I employ a similar argument in "Kant's Non-Absolutist Conception of Political Legitimacy: How Public Right 'Concludes' Private Right in 'The Doctrine of Right'”, Kant Studien (forthcoming), to justify the claim that the legitimacy of the German state dissolved once it introduced laws denying private property to Jews. 
own laws and institutions really do enable reciprocal external freedom under law for all. That is to say, only by protecting the citizens' right freely to express their often controversial and critical responses to the public authority's operations can the public authority possibly take its decisions to represent the common, unified perspective of all its citizens. Without knowledge of how the decisions affect the citizens, it is simply impossible to function as a representative authority. Therefore, the state has the right and duty constitutionally to protect its citizens' right to free speech; the right to free speech is constitutive of the rightful relation between citizens and their state.

There is clear textual support that Kant provides the kind of twofold defense of free speech argued here, namely that communication of thought does not typically involve private wrongdoing and that the state must protect free speech in order to function as a representative authority. To outlaw free speech, Kant argues in the essay "What is Enlightenment?", is to "renounce enlightenment... [and] to violate the sacred right of humanity and trample it underfoot" (8: 39). Outlawing free speech is not only stupid, since it makes enlightenment or governance through reason impossible, but it involves denying people their right of humanity. Their right of humanity is denied by outlawing free speech, because such legislation involves using coercion against the citizens even when their speech does not deprive anyone of what is theirs. Moreover, outlawing free speech evidences a government "which misunderstands itself" (8: 41). Similarly, Kant argues both in this text and in "Theory and Practice" that such legislation expresses sheer irrational behavior on the part of a government. "[F]reedom of the pen", Kant writes in the latter essay,

is the sole palladium of the people's rights. For to want to deny them this freedom is not only tantamount to taking from them any claim to a right with respect to the supreme commander (according to Hobbes), but is also to withhold from the latter - whose will gives order to the subjects as citizens only by representing the general will of the people - all knowledge of matters that he himself would change if he knew about them and to put him in contradiction with himself.... (8: 304, cf. 8: 39f)

Free speech is seen as the ultimate safeguard or protection of the people's rights. Therefore, a public authority - an authority representing the will of the citizens and yet the will of no one in particular - cannot outlaw free speech, since citizens qua citizens cannot be seen as consenting to it. Such a decree would bring the sovereign 'in contradiction with himself' since it would involve denying the sovereign the vital information it needs in order to act as the representative of the people. In "What is Enlightenment?" Kant expands this point: "[t]he public use of one's reason must always be free... by the public use of one's own reason I understand that use which someone makes of it as a scholar before the entire public of the world of readers" (8: 37). Every citizen must have the right to engage truthfully, yet critically in public affairs - to be a scholar - and so to raise her voice and explain why she judges the current public system of laws to be unjust or unfair. If such voices are not raised, the public authority cannot possibly be able to govern wisely; without a public expression of the consequences for right of particular laws, the public authority does not have the information required to secure right for all and so to represent its citizens. 
Above I mentioned that the aim of the state is to establish itself as a representative, liberal system of law, and I also pointed out how this entails that the state must ensure that it rules through liberal law, understood as encompassing both private right measures as well as certain public right measures that enable the sovereign to be representative in nature. This, however, does not constitute Kant's full discussion of what establishing a liberal system of law involves..$^{10}$ Additional public right principles are 'a priori' necessary or constitutive of a liberal system of law. These principles follow from the fact that the state must institutionally reconcile its monopoly on coercion with the rights of each of its citizens and thereby enable its own rightful existence in perpetuity. "Public right" refers not only to individuals' rights, says Kant, but to "[t]he sum of the laws which needs to be promulgated generally in order to bring about a rightful condition" (6:311). These public law measures essentially concern issues of systemic justice, meaning that they are seen as required to secure systemic right for all citizens. The main principle guiding measures ensuring systemic justice is simply that the state cannot allow its citizens to become dependent upon its monopoly on coercion unless it makes sure that the system as a whole is consistent with their innate right to freedom, namely their right not to be subject to anyone's arbitrary choices but only be governed by universal law. The institutional systems upon which the citizens are dependent must respect the citizens as free, equal and independent in relation to one another (6:313) - and public right is the main tool the state has to ensure that public institutions operate in this way.

Kant centers his discussion of systemic justice in "General Remark On the Effects with Regard to Rights that Follow from the Nature of the Civil Union" (6: 318). This section of the "Doctrine of Right" is dedicated to justifying public right principles as they pertain to systemic issues concerning revolution (6: 318-323); land ownership, the economy and the financial system (6: 323-325); poverty and religious institutions (6: 326-328); public offices (6: 328-330), and punishment (6: 331-337). Each of these principles of public right is seen as resulting from how the state must reconcile its monopoly on coercion with each citizens' innate right to freedom, by providing conditions or establishing a systemic institutional whole in which citizens can interact as free, equal and independent in relation to one another. Rather than engage each of these public right principles here, ${ }^{11}$ I will concentrate on those more directly relevant to free speech, namely principles concerning seditious speech, punishment, public offices, and why all crimes are covered by public right rather than private right. Subsequently, I will treat contemporary issues surrounding hate speech, speech amounting to harassment, and blackmail.

\footnotetext{
${ }^{10} \mathrm{Hence}$, even if the voluntarist would agree with Kant up to this point, I take it that the voluntarist position cannot make sense of the need for the additional provisions for systemic justice. Therefore, if the argument presented below succeeds, then voluntarism as it is typically understood fails as a liberal approach to analyze the state's coercive authority.

${ }^{11}$ See my "Kant and Dependency Relations: Kant on the State's Right to Redistribute Resources to Protect the Rights of Dependents", Dialogue XLV (2006): 257-284, and "Kant's NonAbsolutist Conception of Political Legitimacy" (Kant-Studien, forthcoming) for further discussion of these public right principles.
} 
To understand Kant's condemnation of seditious speech, remember that Kant, as mentioned above, takes himself to have shown that justice is impossible in the state of nature or that there is no natural executive right. Since Kant considers himself to have successfully refuted any defense of the natural executive right, he takes himself also to have shown that no one has the right to stay in the state of nature. This, in turn, explains why Kant can and does consider seditious speech a public crime. The intention behind seditious speech is not merely to criticize the government or to discuss theories of government critically, say. In order to qualify as seditious, the speaker's intention must be to encourage and support efforts to subvert the government or to instigate its violent overthrow, namely revolution. To have such a right would be to have the right to destroy the state. Since the state is the means through which right is possible, such a right would involve having the right to annihilate right (6: 320). That is, since right is impossible in the state of nature, to have a right to subversion would be to have the right to replace right with might. Since the state is the only means through which right can replace might, the state outlaws it. And since it is a crime that "endanger[s] the commonwealth" rather than citizens qua private citizens, it is a public crime (6: 331$)$.

The refutation of a natural executive right also explains why Kant holds that public right covers speech amounting to a private crime, such as a serious contractual lie. An act of aggression, or coercion, against another person is also an attempt to undermine the state's rightful monopoly on coercion. Hence all violent aggressions, including serious contractual lies, are crimes covered by public law - what we call 'private crime laws'. They are not regulated by private law $(6: 331)$.

Public law also governs the public authority's administrative offices (6: 328). Only in this way can it subject its citizens to the authority of these offices without thereby subjecting them to other citizens' (the public officers') arbitrary choices. Public law regulation of public administrative offices creates the distinction between reasoning as a public officer and as a private citizen. Right, therefore, requires more than a properly functioning public reason. It also requires that public officers respect what Kant calls, somewhat misleadingly, the 'private' reasoning (8: $37 \mathrm{f}$ ) constitutive of their office. ${ }^{12}$ The distinction between 'scholarly' or public reasoning qua citizen and 'private' reasoning qua public officer is necessary to reconcile the public authority's power with each citizen's right to freedom. Thus can public offices function as representative of the citizens and ensure interaction subject to universal laws of freedom rather than to anyone's particular choices.

Kant's distinction between public and private right can also be used to make sense of controversial issues of hate speech, speech amounting to harassment, and blackmail. First, an explanation why all these kinds of speech will not only be regulated in relation to public spaces, but also private (non-governmental) workplaces. The reason why public spaces of interaction and private workplaces are equally

${ }^{12}$ For an excellent discussion of Kant's distinction between private and public reason, see Jonathan Peterson's "Enlightenment and Freedom," Journal of the History of Philosophy, Vol. 46, No. 2 (April 2008): 223-244. 
important targets of public law issues from the fact that in capitalist economies, at least, the state has permitted its citizens to become dependent upon private employment to secure access to means and hence to exercise external freedom. Just as the state must ensure that all public spaces are spheres within which its citizens can interact as free, equal and independent bearers of rights, the state must also ensure that an economy on which its citizens are dependent for access to material means functions in the same way. That is to say, insofar as the state permits the capitalist system to become part of the public solution to enabling rightful private property for all, it must also govern that economic system by public law. The state cannot permit such systemic dependence without also ensuring that the systems are not under private control. To permit this would be to permit some private citizens to obtain coercive control over the freedom of other citizens, which is precisely not to ensure that universal law regulates all citizens' interactions. ${ }^{13}$ Such private dependency relations are therefore necessarily in conflict with the state's function, namely to reconcile its monopoly on coercion with each citizen's innate right to freedom. The right to freedom, as we saw, is the right to independence from rather than dependence upon any private person's arbitrary choices, which is realized only by subjecting interacting persons' freedom reciprocally to universal laws of freedom as enabled by the public authority. By issuing public law to govern any systems, including private ones, upon which the citizens' exercise of their rights is dependent, the state secures rightful conditions for all.

Even if we accept that issues of systemic dependency explain why the state will regulate public spaces as well as some apparently private interactions, such as in the workplace, it is not immediately clear why the regulation of hate speech and speech amounting to harassment is necessary. ${ }^{14}$ Why are these kinds of speech not protected by free speech legislation - and why do they fall under public rather than private law? The answer lies in the way in which these kinds of speech track severe and pervasive historical oppression. Hate speech and harassment are exemplified by personal insults on the basis of factors like race, ethnicity, gender, sexual orientation, disability and socioeconomic class. Moreover, it seems that achieving the insult is possible only because there has been a significant history of oppression of the insulted person. After all, blond jokes can't really rise to the status of insult, but sexist comments about my gender can. ${ }^{15}$ Still, as we saw above, the fact that speech is offensive or annoying is not enough to make them proper objects of law, so what makes these cases different?

On the Kantian view I have been developing, hate speech and speech amounting to harassment are not outlawed because they track private wrongdoing as such, but

\footnotetext{
${ }^{13}$ I think this argument applies to any private system on which the state allows its citizens to be dependent for the exercise of their rights.

${ }^{14}$ Note that libertarian theories of justice have a hard time making sense of these kinds of regulation. Because they are committed to the view that the rights of the state are reducible to those of individuals, any restrictions must be understood in terms of private harms.

${ }^{15}$ See Ann E. Cudd, Analyzing Oppression (New York: Oxford University Press, 2006) for an excellent discussion of these features of oppression.
} 
rather because they track the state's historical and current ${ }^{16}$ inability to provide some group(s) of citizens with rightful conditions of interaction. This type of public law tries to remedy the fact that some citizens have been and still are "more equal than others'. Hence, if the state finds that it is still unable successfully to provide conditions under which protection and empowerment of its historically oppressed, and thus vulnerable, are secured, then it is within its rightful powers to legally regulate speech and harassment to improve its ability to do so. By putting its weight behind historically oppressed and vulnerable citizens, the state seeks to overcome the problems caused by its lack of recognition in the past and its current failure to provide conditions in which its citizens interact with respect for one as free and equal. Therefore, whether or not any instance of speech actually achieves insult is inconsequential, for that is not the justification for the state's right to outlaw it. Rather, laws regulating speech and harassment track the state's systemic inability to provide rightful interaction for all of its citizens. Note that this argument does not, nor must it, determine which particular usages of hate speech and speech amounting to harassment should be banned. It only explains why certain kinds and circumstances of speech and harassment can and should be outlawed and why public law, rather than private law, is the proper means for doing so. Determining which types and how it should be banned is matter for public debate and reflection followed by public regulation on behalf of all citizens.

Finally, why is blackmail a matter of public right $?^{17}$ As we have seen above, private right protects each person's right to use his own means to pursue his ends. Moreover, we have seen that no one has a right to anyone else's silence. Insofar as I have obtained knowledge about something by rightful means, including another person's history, that knowledge belongs to me. And I can make available to others if I so choose. ${ }^{18}$ So why can't I offer my silence with respect to another's history in exchange for some material means, such as money? The reason why I do not have a right to blackmail is that this kind of silence falls within the public sphere, and with regard to this sphere, as we have seen, all citizens must be provided conditions in which they can interact as free, equal and independent. Instances of blackmail subvert these conditions because they result in one citizen becoming dependent upon another for the exercise of rightful freedom. Providing conditions of rightful interaction precludes that one person can set ends that aim to subject another person's

\footnotetext{
${ }^{16} \mathrm{As}$ is well known, criminal statistics affirm that ethnic and religious minorities, women, gays and lesbians, for example, are still frequent subjects of violence - whether by private individuals or by public officials - merely in virtue of their ethnic, religious or gender identity and their sexual orientation. Naturally, the fact that violence against citizens due to their sexual orientation is not covered in hate crime legislation in many U.S. states does nothing to mitigate this point. Rather, it signals one way the state currently fails to enable conditions of rightful interaction for all of its citizens.

${ }^{17}$ I am tremendously grateful to David Sussman and Arthur Ripstein for discussion on this point, which, of course, is not to say that they necessarily agree with my view.

${ }^{18}$ There are some exceptions to this general rule, such as, for example, we find in doctor-patient and attorney-client privilege, that I cannot consider here.
} 
freedom to her choices in this way. Therefore, although I am permitted to make whatever truthful information I have about someone available to the public, perhaps by selling it to a newspaper or a magazine, I am not permitted to approach that person with an offer to exchange my silence (my means) for some of her means. To do so constitutes an attempt to force her into a private dependency relation with me, rather than to interact as free, equal and independent persons. Hence the state outlaws blackmail by means of public law. It is a public crime, since it endangers public right as such.

\section{Conclusion}

The aim of this paper has been to show that rather than being an outdated and peculiar account of free speech, Kant's position has something important and powerful to contribute to the current debate. I have argued that part of what makes Kant's account particularly interesting to contemporary discussions issues from the distinctions drawn between virtue and right and between private and public right. These help to clarify and justify the principled distinctions that liberal law is currently struggling with, including distinctions between free speech, seditious speech, hate speech, harassment, defamation and blackmail. 